\title{
Festival des 3 Continents 2001
}

\author{
By Gönül Dönmez-Colin
}

Spring 2002 Issue of KINEMA

\section{FESTIVAL DES 3 CONTIENTS: A VIRTUAL VOYAGE OF DISCOVERY}

Festival of Three Continents (20-27 November 2001), which has been taking place for 23 years in the French city of Nantes near the Atlantic coast -- the city of Jules Verne and the Montgolfier brothers- continued its tradition of displaying recent films from Asia, Latin America and Africa this year with a refined selection that seemed to favour Asia. Such an imbalance was not surprising, since there are very few quality films made in Africa or Latin America today.

Nantes is a festival first and foremost for the people of the city although many professionals from all over the world attend this adventurous and intellectually stimulating event regularly. Alain and Philippe Jalladeau, the directors of the festival who laid the foundations almost a quarter of a century ago roam the three continents each year to discover unknown territories and to bring back home to the faithful audience rewarding surprises. In Nantes, you may find films from countries such as Kyrgyzstan, Uzbekistan, Mongolia or Malaysia that even the most dedicated critics know only as a spot on the world map.

The festival regularly shows around ten new films in competition and a number of other quality films out of competition; the latter are films that have already received ample attention elsewhere.

This year's competition included Delbaran (2001) by Abolfazl Jalili, an exceptional Iranian director who works independently of any governmental organization in his country. In fact, none of his accomplished films has ever been shown in Iran except within the context of the annual Fajr International Film Festival. Winner of several foreign awards for each of his films, Jalili often uses the landscape as an important protagonist in his films that follow a script that is a closely guarded secret that develops each day inside his head as the shooting progresses. Delbaran is the story of a young Afghan illegal, Kaim who runs errands for an old couple operating a café at a border town. Determined not to shed a single tear for the parents that he had lost to war or for the sister he left behind, Kaim runs back and forth non-stop trying to appear tougher than he really is. The film has a deep humanism that touches the heart without being sentimental. The scene when the kind doctor establishes a rapport with Kaim -the only time Kaim lets go of his survival mask- is a rare moment of exceptional cinema. A clandestine marriage in a cave normally inhabited by the sheep is, as absurd as it can be, but it brings in the comic relief much needed at this point. As the official arrives to arrest the groom who is an illegal Afghani, he wants to know why the man is marrying an Iranian girl. The answer (through the interpreter) is that he loves her. How would he communicate with her when he does not even speak Persian? The answer again is that he loves her. This is also a reminder that the old road between the two countries which has now become obsolete because a new road is being built, used to be called Delbaran, meaning love road. Although most of the films in competition were important works, Delbaran certainly deserved the top prize, Golden Montgolfier as it did.

Hai Xian (Seafood, 2001) by Zhu Wen from China is a strange film rather difficult to watch. A prostitute from Beijing goes to a summer resort in wintertime to kill herself. A policeman spots her and begins to use every possible method (including rape) to stop her. The somewhat bizarre relationship that ensues is a strong metaphor for the relationship of the Chinese citizens to the State. Zhu Wen shows remarkable talent is handling such a risqué subject in this film that was very favourably received in Venice past year.

Gaichu (Harmful Insects, 2001) by Japanese filmmaker Akihiko Shiota who has in the past explored adolescence and sexuality with films such as Moonlight Whispers and Don't Look Back (1999) has a young protagonist who has had a relationship with her teacher when she was in sixth grade. Now she is 12 years old living with her mother who has more problems than her, the father having disappeared some years ago with his mistress. The film reflects the issues of the new Japanese family where the traditions have faded but not yet been replaced by something else.

Dekha (Perceptions, 2001) by Goutam Ghose from West Bengal in India is a film that explores the issues of sight, perception, memory and art in a period of change as an aristocrat intellectual faces his obsoleteness 
in a world that has become too materialistic. Ghose, who has won awards with his previous films in Nantes, explores the inner world of his protagonist in an unhurried fashion as the striking images of new Calcutta's hustle and bustle infringe upon the apparent paradisiacal tranquillity of the hero's surroundings.

Among the films Out of Competition, from Kazakhstan, the protagonist of Darejan Omirbaev's Jol (The Road, 2001) is a filmmaker called Amir, who has to return to his village to be on the side of his dying mother. While he is driving, the road disappears from the rear window as a past left behind before the camera focuses on the face of the protagonist who is troubled, uncertain and most of all, devoid of energy. His mind wonders to his editing room where he is caught by his wife while flirting with his assistant. In an auditorium where his film is supposed to have its first screening, Amir declares to the audience that a film is 'naked in front of an audience. No one judges a science project as good or bad. There is no objective way to evaluate a film" and he concludes, "the hardest job of all is to be a director." The projectionist mixes up the reels and puts a karate film instead. The worse part is that the audience prefers this film to his. His mind wanders to the beating he received in his living room from the brother of a girl who was compromised when naked body of another actress was montaged as hers in the erotic scenes of his film. Integrity of the artist, to his art, to society and to himself stays a big question mark.

Omirbaev does not resort to stylistic decoders, such as black and white for the past etc. Everything blends and becomes one, as part of a man's life, a man coming to terms with his part, present and future at a crucial moment in his existence. A tribute to Kazakh filmmakers by one of its finest, the film is also a forceful statement on the film industry of Kazakhstan, where $J o l$ was the only film produced this year and that was only possible with French money.

Kazakhstan was the country of focus this year along with Kyrgyzstan with fine examples of landmark films of the last thirty years. Kyrgyz Aktan Abdykalykov's Maimil (The Chimp, 2001), which is the last part of the trilogy that includes the medium-length Sel'kincek (The Swing, 1993) and the feature Beshkempir (The Adopted Son, 1998) is a bittersweet story of becoming an adult in a remote town of the Kyrgyz steppes. Autobiographical as the previous two films, the role of the protagonist is again interpreted by the director's son, Mirlan who has become somewhat of an alter ego of his father. Just as Jol, Maimil was also produced with funds from France.

Kazakh film industry is in much better shape than Kyrgyz film industry where there are hardly any films made today, but neither country has a chance to continue its cinematic tradition without foreign assistance.

The festival paid homage to Katy Jurado, an exceptional Mexican actress who started her career in 1943 working with world known filmmakers, from Luis Buñuel to John Huston. Her last appearances were in 1998 in El Evangelio de las Maravillas of Arturo Ripstein and Stephen Frears' The Hi Lo Country. Nour El Cherif, an Egyptian star who played in more than 200 films over a career of 35 years was also paid homage.

A real delight for the audience was a selection of 'sword films' from Hong Kong covering 30 years of the genre. World attention has been drawn to the cloak-and-dagger genre with the success of Crouching Tiger, Hidden Dragon of Ang Lee, but the genre was in existence even in the silent era. Mixing legends, history, magic and martial arts, it has been incorporated into every facet of Chinese cinema. The most remarkable and prolific period, however was the sixties in Hong Kong (in the Shaw Brothers' and Cathay Studios) where the film industry settled after the war and Mao's coming to power. The festival screened a dozen films from Dragon Gate Inn (King Hu, 1967) to Dao (The Blade, Tsui Hark, 1995).

A pleasant surprise was films of two talented filmmakers from Malaysia, a country, which does not appear even in the most refined film map. It was interesting to find out that in the last decade, Malaysia has been producing fifteen films each year albeit under the tight control of censorship. These films are mostly genre films, which are increasingly leaning on the commercial side to meet the production costs. Some of the younger filmmakers have begun to shoot in English for export possibilities. Uwei Hajisaari, a controversial but celebrated figure of Malaysian cinema attended the festival with a number of his films, including Perempuan, Isteri, Jalang (Woman, Wife and Prostitute, 1993) which is still banned in Malaysia and Khaki Bakar (The Arsonist, 1995), the only Malaysian film ever shown at Cannes.

Osman Ali built up the story of Bukak Api (Open Fire, 2001) around the plight of transsexual sex-workers who lead extremely vulnerable lives. Rejected by their families, they depend on each other for trust, love 
and the courage to fight in this film shot in the style of a documentary.

At the end of the festival, Asian films received most of the awards as was expected and the curtain closed with the traditional feast of local oysters washed away with the local white wine, Muscadet.

\section{References}

\section{AWARDS}

Golden Montgolfier: Delbaran by Abolfazl Jalili, Iran

Silver Montgolfier: Dekha by Goutam Ghose, India

Special Jury Award: Harmful Insects by Akihiko Shiota, Japan

Best directing Award, tribute to Jacques Demy: Seafood by Zhu Wen, China

Jury Mention for best photography: Calmness by Jayaraj, India

Best Actress: Aoi Miyazaki for Harmful Insects

Best actor ex-aequo: Cheng Taisheng in Seafood and Mohamed Majd in The Wind Horse by Daoud Aoulad Syad, Morocco

Young Audience Award: The Wind Horse

Audience Award: Human Comedy by Hung Hung, Taiwan

\section{Author Information}

Gönül DÖNMEZ-COLIN is an independent researcher and writer whose publications include Women, Islam and Cinema, Cinemas of the Other: A personal Journey with Filmmakers from the Middle East and Central Asia, Cinema of North Africa and the Middle East (ed.); Turkish Cinema: Identity, Distance and Belonging (Reaktion Books), and Routledge Dictionary of Turkish Cinema (2014). 